\title{
Seed productivity and reproduction features of Schisandra chinensis under conditions of the M.M. Gryshko National Botanical Garden
}

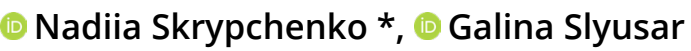 \\ M.M. Gryshko National Botanical Garden, National Academy of Sciences of Ukraine, Tymiryazevska str. 1, 01014 Kyiv, Ukraine; \\ * actinadiia@gmail.com
}

Received: 26.05 .2020 | Accepted: 24.10.2020 | Published: 30.12 .2020

\begin{abstract}
Data on seed productivity and peculiarities of reproduction of Schisandra chinensis under the conditions of introduction at the M.M. Gryshko National Botanical Garden of the National Academy of Sciences of Ukraine (NBG) are discussed. The study was carried out in 2016-2018 on experimental fields and in the NBG laboratory using plants and seeds of Ukrainian selection S. chinensis 'Sadovyi-1'. Sections were examined with the microscope Carl Zeiss STEMI 2000-S. Qualitative and quantitative composition of higher fatty acids has been identified by HP-6890 chromatograph. It was found that $S$. chinensis of local reproduction have a much lower percentage of the seeds without embryo (about $10 \%$ ) compared to those of natural origin (30-90\%). Because of long-term storage of S. chinensis seeds the biochemical transformations take place: the content of fats and proteins decreased from 37.5 to $28.0 \%$, and from 19.7 to $11.2 \%$, respectively, the acid number of oil increased from 2.42 to $5.70 \mathrm{mg} \mathrm{KOH} / \mathrm{g}$, and its iodine value decreased from 32.5 to $30.3 \mathrm{~g} \mathrm{I}_{2} / 100 \mathrm{~g}$ after storage of seeds during ten months. Fatty oil of S. chinensis seeds has a high linoleic acid content, which reaches $80-81.1 \%$ of the total content of fatty acids. The storage of seeds under different illumination and temperature conditions resulted in minor changes in the acid number of the oil and the quantitative content of fatty acids. The optimal storage conditions of seeds (without access to light and at the temperature of $+4^{\circ} \mathrm{C}$ ) were determined. Such storage conditions reduce the intensity of oxidative processes in the seeds, ensuring the highest germination rate. The optimal ways of $S$. chinensis reproduction by seeds are the spring sowing of stratified seeds and autumn sowing of freshly reaped seeds, which gain natural stratification. Using these ways resulted in $65 \%$ and $63 \%$ of seeds germination, respectively.
\end{abstract}

Keywords: Schisandra chinensis, seed, shelf life, reproduction features, biochemical composition

\section{Introduction}

Schisandra chinensis (Turcz.) Baill. is the valuable fruity, medicine, and decorative plant from the family Schisandraceae Blume (Saunders, 1997; Szopa et al., 2016). Its fruits are rich in bioactive compounds and are used in food industry, medicine, and cosmetology (Kolbasina et al., 2008; Nowak et al., 2019). Since ancient times fruits of S. chinensis have been used by Chinese and Tibetan physicians as a tonic remedy for physical tiredness, nervous system exhaustion, neurasthenia, hypotonia, and its seeds have been used for phthisis, bronchial asthma, liver and kidneys diseases, and dysentery treatment (Kolbasina, 2000; Lebeda et al., 2006; Szopa et al., 2016). The lipid complex of S. chinensis seeds demonstrates the adaptogenic, tonic, immunostimulation, antipyretic and regenerative effects (Lebeda et al., 2006; Skrypchenko et al., 2017). According to recent investigations, compounds of S. chinensis also 
have an anti-cancer effect, inducing the cell cycle interruption and apoptosis, inhibition of invasions and line metastasizing of cancer cells, as well as antimicrobial and antidiabetic action (Nowak et al., 2019).

Schisandra chinensis is a JapaneseManchurian endemic. It is relict plant of the Neogene. Medicinal raw materials of S. chinensis were intensively harvested in natural occurrence places, which led to a significant reduction of its population. In this regard and the regard of growing demands, irregular fruiting, and yielding, this species has been included in the Red Book of Sakhalin Region (Kharkevich \& Kachura, 1981).

Schisandra chinensis was introduced in Ukraine more than 60 years ago. Plants blossom and fruit abundantly, providing mass reproduction by seeds. A perspective cultivar 'Sadovyi-1' has been obtained, and perspective form '1-1' with female flowers has been selected at the M.M. Gryshko National Botanic Garden of the National Academy of Sciences of Ukraine (NBG) (Skrypchenko et al., 2017). However, the introduction of $\mathrm{S}$. chinensis into gardening is restrained mostly due to the difficulty of its reproduction. Schisandra chinensis mostly reproduces vegetatively, and seed-derived individuals are almost absent in nature (Kolbasina, 2000). Along with this, $\mathrm{S}$. chinensis is mostly cultivated from seeds, and selected forms are vegetatively fixed then (Plekhanova, 1990).

Seeds of S. chinensis vary in size, weight, color, and embryo size (Kolotova \& Nikolaeva, 1981). Some seeds have weak germination capacity due to an underdeveloped (inert) embryo that can not sprout even after extensive preparation. From 30 to $90 \%$ of S. chinensis seeds do not ripen due to lack or undeveloped embryo, which is probably associated with long cold spring and rainy summer (Tytlianov, 1959; Gurevich, 2012; Alekseichuk \& Laman, 2005). The endosperm of such seeds has crumbly and floury consistency. Hence, only big and well-filled seeds can be used for sowing (Plekhanova, 1990).

After fruit ripening, S. chinensis seeds go to dormancy, as it happens in most plants. Dormancy is followed by deep physical and biochemical changes in seeds' cells and tissues. This is one of the most important adaptive features reached in the process of seed plants evolution, that promotes species preservation, providing the seed germination only in conditions, which are favorable for development (Footitt et al., 2013; Willis et al., 2014; Soppe \& Bentsink, 2016). Seeds of $\mathrm{S}$. chinensis have endogenic dormancy caused by embryo underdevelopment and its physiological state (Nikolaeva et al., 1985). It germinates only after stratification, which complicates the artificial seed reproduction of this species.

Seeds of S. chinensis are rich in fatty oils (up to $33 \%$ ) and, hence, belong to the oil type of seeds. Such seeds lose their viability under uncontrolled conditions (Roberts, 1972). It is associated with oxidation of lipids and other biochemical processes, which lead to membrane destruction, including those of mitochondria (McDonald, 1999). Preservation of seeds with high oil content is a challenging task, as they are affected by different environmental factors during the storage (mainly by temperature, humidity, and light). Light mostly stimulates the seeds' germination. However, its long effect usually depresses it (Malov \& Vigorskiy, 2002). This is why this work aimed to determine the optimal terms and conditions of S. chinensis seeds storage.

\section{Material and methods}

The research was performed in 2016-2018 at the NBG experimental fields and laboratory using seeds and plants of $\mathrm{S}$. chinensis 'Sadovyi-1'.

The area's climate, where the NBG is located, is moderately continental with an average annual temperature $9.4^{\circ} \mathrm{C}$, average temperature in January $--5.5^{\circ} \mathrm{C}$, and average temperature in June $+20.4^{\circ} \mathrm{C}$. Periodic changes of Atlantic air masses soften the winter in Kyiv. The frost-free period is about 165-180 days. According to the longterm data, the sum of active temperatures in Kyiv is $2000-2500{ }^{\circ} \mathrm{C}$. The average annual amount of precipitation is $550-650 \mathrm{~mm}$, and relative humidity is $73-76 \%$ (Osadchyi et al., 2010). The duration of frost-free period, temperature, and rainfall during the active growing season cause suitable conditions for the successful cultivation of different fruit plants from regions with similar and more moderate climate conditions. 
Table 1. Biometric parameters of Schisandra chinensis 'Sadovyi-1' fruits.

\begin{tabular}{lllllllllllll}
\hline \multirow{2}{*}{ Indexes } & \multicolumn{4}{c}{2016} & \multicolumn{1}{c}{2017} & \multicolumn{1}{c}{2018} \\
\cline { 2 - 13 } & $\mathrm{M} \pm \mathrm{m}$ & $\mathrm{Max}$ & $\mathrm{Min}$ & $\mathrm{CV}, \%$ & $\mathrm{M} \pm \mathrm{m}$ & $\mathrm{Max}$ & $\mathrm{Min}$ & $\mathrm{CV}, \%$ & $\mathrm{M} \pm \mathrm{m}$ & $\mathrm{Max}$ & $\mathrm{Min}$ & $\mathrm{CV}, \%$ \\
\hline Fruit mass, g & $9.6 \pm 2.1$ & 16.5 & 6.6 & 21.3 & $10.7 \pm 2.9$ & 14.0 & 4.5 & 27.9 & $10.5 \pm 3.2$ & 15.7 & 5.8 & 29.7 \\
Peduncle mass, $\mathrm{g}$ & $1.0 \pm 0.4$ & 1.7 & 0.5 & 39.2 & $0.6 \pm 0.2$ & 1.0 & 0.3 & 35.4 & $0.9 \pm 0.2$ & 1.5 & 0.4 & 39.8 \\
Fruitlets number & $24.3 \pm 0.6$ & 35.0 & 13.0 & 25.3 & $30.2 \pm 2.9$ & 34.0 & 26.0 & 9.6 & $28.3 \pm 4.3$ & 34.0 & 21.0 & 15.2 \\
Fruit length, cm & $10.7 \pm 1.7$ & 14.8 & 7.4 & 16.1 & $6.5 \pm 1.4$ & 8.8 & 4.6 & 21.2 & $6.9 \pm 1.9$ & 10.8 & 5.4 & 28.2 \\
Seed length, mm & $3.5 \pm 0.2$ & 4.0 & 3.0 & 6.3 & $3.4 \pm 0.2$ & 3.8 & 2.9 & 7.5 & $3.4 \pm 0.3$ & 3.9 & 2.9 & 9.5 \\
Seed width, mm & $2.8 \pm 0.2$ & 3.2 & 2.3 & 6.9 & $2.7 \pm 0.1$ & 3.1 & 2.2 & 7.1 & $2.7 \pm 0.1$ & 3.2 & 2.3 & 11.4 \\
\hline
\end{tabular}

Note. $\mathrm{M} \pm \mathrm{m}$ - mean value and standard deviation; Max - maximal value; Min - minimal value; CV - coefficient of variation.

Sections examination was performed with a light microscope Carl Zeiss STEMI 2000S (Germany). Fatty acids were obtained by the press method. Qualitative indicators, namely iodine and an acid number of oil, were determined following Gonchar (2000). The qualitative and quantitative composition of the higher fatty acids (HFA) was identified by HP6890 chromatograph using quartz columns of $0.35 \mathrm{~mm}$ diameter and an immobile phase of 5\% sinilmethylsiloxan (Rivis \& Fedoruk, 2010). HFA were identified by comparing their methyl ethers retention time and the retention time of peaks of standard compounds. A He-Ne laser with a $632.8 \mathrm{~nm}$ wavelength was used to irradiate the seeds. Exposure time was about 20 seconds.

To identify the optimal terms of seeds storage without losses of viability, the comparative investigation of oil's properties from freshly reaped seeds and seeds stored under $15-25 \pm 1^{\circ} \mathrm{C}$ temperature for five and ten months was performed. Statistical analysis was performed using the MS Excel 2010

\section{Results and discussion}

Many years of research of $\mathrm{S}$. chinensis developmental biology under the NBG conditions showed that these plants take the full developmental cycle and have the annual blossoming and abundant fruiting. The fruit of S. chinensis is a juicy aggregate follicetum, similar to cylindric raceme $4.6-14.8 \mathrm{~cm}$ in length and bearing 13 to 34 red fruitlets (Table 1). The mass of one fruit is $4.5-16.5 \mathrm{~g}$, and one plant (15-20 years old) gives up to
$2.5 \mathrm{~kg}$ of fruits in total. Each berry contains one-two seeds, and generally, seeds represent about $64 \%$ of the fruitlet mass. The mass of 1000 seeds is $26.5 \pm 2.1 \mathrm{~g}$.

The seeds of S. chinensis of local reproduction are kidney-shaped with a smooth, shiny surface and rough peel. Seed peel usually has many layers: external epidermis, adjoining 4-6 rows of highly lignified stony cells of the sclerenchyma, under which the inner layer of the seed coat is located, consisting of parenchymatic thin-walled tissue. The main seed volume is occupied by dense endosperm, containing polyhedral cells with fatty oil drops and very small aleurone cells 8-15 $\mu \mathrm{m}$ in diameter. The embryo is heart-shaped, slightly differentiated (0.3-0.6 cm in length, diameter does not exceed $0.2 \mathrm{~cm}$ ). The embryo is located at the narrow part of the seed. Seeds without an embryo (Fig. 1) comprise about 10\%.

A slightly higher content of fatty acid (37.5\%) comparing to the literature data (33\%) has been detected during our investigations (Kolbasina et al., 2008). Moreover, some changes in its qualitative and quantitative composition were identified during storage. In particular, oil content in seeds decreases under conditions of prolonged storage. Thus, the mass ratio of oil in seeds was 37 and $28 \%$ after five and ten months of storage, respectively (Table 2). The acid number of oil from freshly reaped seeds was 2.42 , while for the seeds stored five and ten months, it was 2.82 and 5.70, respectively. The highest acid number was noted for seeds with the most extended storage term, indicating the the oxidation of lipids. Protein content was 

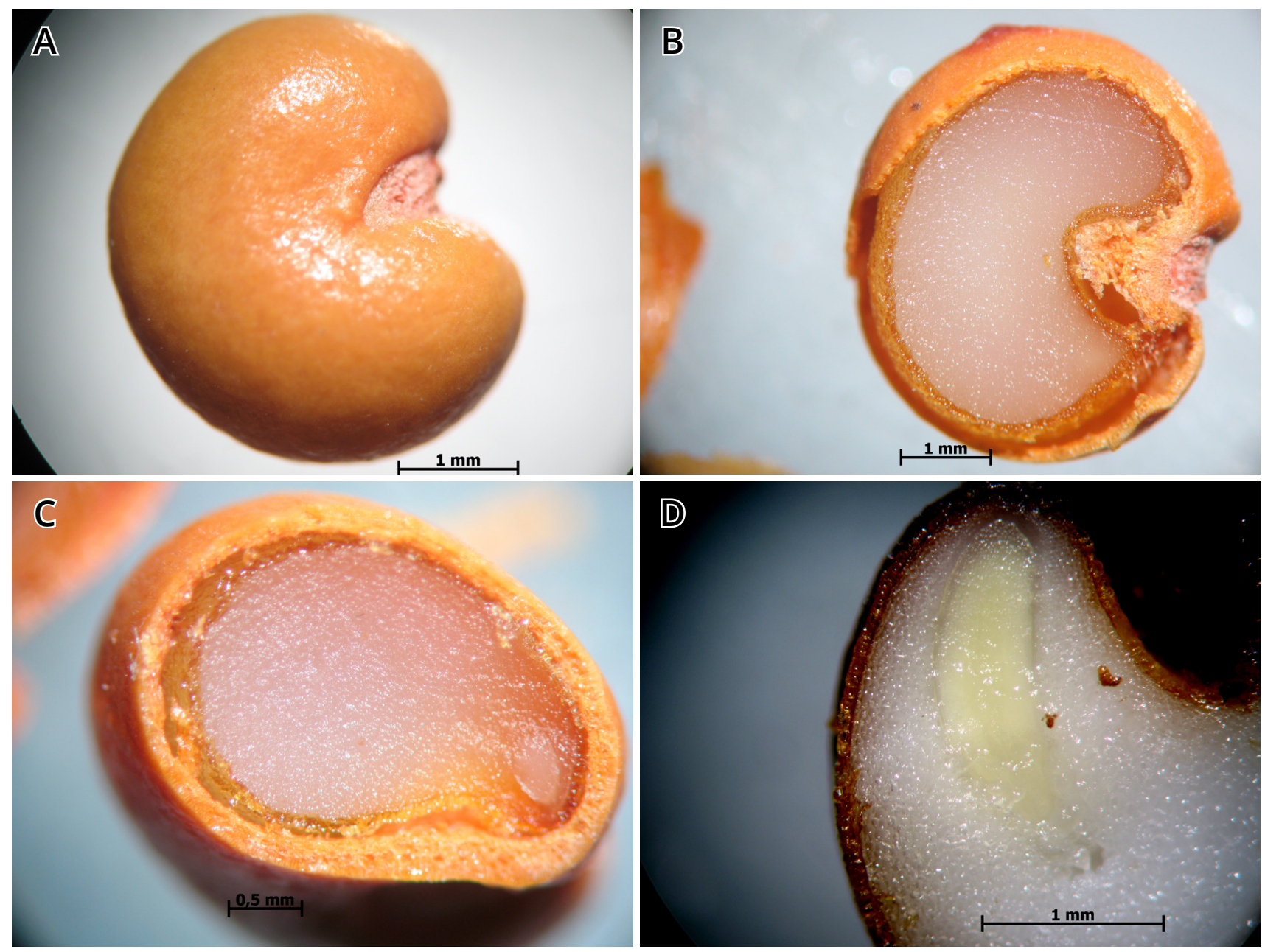

Figure 1. Schisandra chinensis 'Sadovyi-1': A - common view of the seed; B - seed without embryo; C - seed section with the embryo; D - seed section after stratification.

the highest for freshly reaped seeds $(19.7 \%$ in terms of dry weight), while for the seeds stored five and ten months, it was 15.6 and $11.2 \%$, respectively.

The effect of different seeds' storage regimes (different temperature, with and without light) on viability, germination, qualitative and quantitative characteristics of the fatty acid composition of $\mathrm{S}$. chinensis seeds has been evaluated (Fig. 2). Our research showed that oil from S. chinensis seeds contains mostly unsaturated fatty acid ethers with one (oleic acid) and two (linoleic acid) double bonds that are relatively unstable in storage and easily get oxidized. Worth to note that linoleic acid was dominant in the examined raw material (80.0-

Table 2. Chemical composition of Schisandra chinensis 'Sadovyi-1' seeds and indexes of oil with different storage terms.

\begin{tabular}{llll}
\hline \multirow{2}{*}{ Indexes } & \multicolumn{2}{c}{ Seeds } \\
\cline { 2 - 4 } & freshly gathered & stored five months & stored ten months \\
\hline Moisture, \% & $16.3 \pm 1.8$ & $12.7 \pm 1.3$ & $9.8 \pm 1.0$ \\
Fat, \% & $37.5 \pm 2.5$ & $37.0 \pm 2.8$ & $28.0 \pm 2.3$ \\
Protein, \% & $19.7 \pm 1.3$ & $15.6 \pm 1.5$ & $11.2 \pm 1.0$ \\
Oil acid number, $\mathrm{mg} \mathrm{KOH} / \mathrm{g}$ & $2.4 \pm 0.2$ & $2.8 \pm 0.2$ & $5.7 \pm 0.3$ \\
Oil iodine number, $\mathrm{g} \mathrm{I}_{2} / 100 \mathrm{~g}$ & $32.5 \pm 2.9$ & $32.5 \pm 2.8$ & $30.3 \pm 2.8$ \\
\hline
\end{tabular}



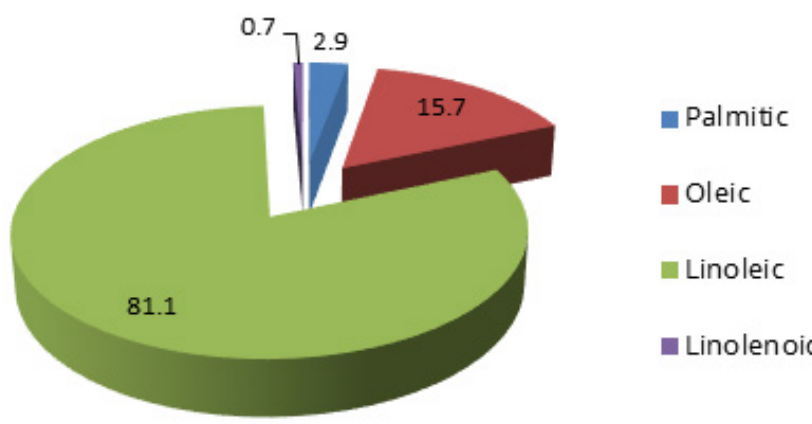

Figure 2. Fatty acid composition of Schisandra chinensis 'Sadovyi-1' seeds oil, \%.

81.1\%). Moreover, its content was five times higher than another unsaturated acid - oleic acid, the content of which was $14.6-15.7 \%$ only.

Oil from seeds stored under the temperature of $+4 \pm 2{ }^{\circ} \mathrm{C}$ and without light has an acid number 2.3 and was the highest in the content of oleic, linolenic, and linoleic acids. While the oil from seeds stored under the temperature range $+20 \pm 2{ }^{\circ} \mathrm{C}$ and light access has less of these acids - the acid number of this oil was 2.42. This indicates that storage conditions affect the intensity of the biochemical changes occurring in the seeds. The highest percentage of germination had the seeds stored under decreased temperature $+4 \pm 2^{\circ} \mathrm{C}$ and without light.

Seed ground germination depends on presowing preparation such as stratification, scarification, thermal and chemical processing (Nikolaeva et al., 1985). Therefore we examined different pre-sowing preparations and sowing terms of S. chinensis seeds (Fig. 3).

The highest index of ground germination (65\%) has been obtained for stratified seeds with the spring sowing $\left(10-20^{\text {th }}\right.$ of April). Autumn sowing, during which the natural stratification occurs, resulted in slightly lower germination $-63 \%$.

Seeds of S. chinensis showed a different dormancy level, $19 \%$ of seeds germinated just after heat stratification.

Laser irradiation has a stimulating effect on germination energy, yield, and stability of cereals, vegetables, and fodder plants (Inyushin, 1981; Malov \& Vigorskiy, 2002). Similarly, our investigations showed that presowing He-Ne laser irradiation of the longterm stored seeds of $\mathrm{S}$. chinensis increased their germination up to $50 \%$.

The germination of the sown seeds began in the middle of May irrespectively to pre-sowing

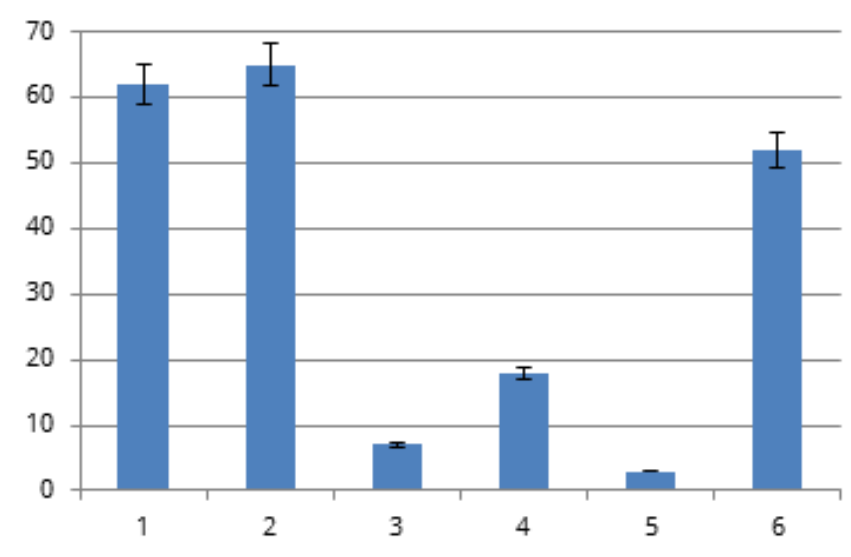

Figure 3. Germination of Schisandra chinensis 'Sadovyi-1' seeds after different pre-sowing preparation techniques applied, in \%: 1 - autumn sowing of freshly picked seeds; spring sowing: 2 - after stratification; 3 - unstratified; 4 - after thermal stratification; 5 - unstratified long-term (16 months) storage; 6 - unstratified long-term storage with He-Ne laser irradiation.

preparation. S. chinensis has above-ground germination of the seeds, characterized first by appearing of hooked hypocotyl, which straightens in ten days. After leaving the seed coat, two seminal leaves open become green. Sprouts' epicotyl is anthocyanine-reddish, up to $3 \mathrm{~mm}$ in length and about $1.5 \mathrm{~mm}$ in diameter. One-year-old sprouts of S. chinensis by the end of vegetative period reach up to $5 \mathrm{~cm}$ in height, have 5-14 leaves, and root system with weakly developed main root and 20-25 lateral roots of the first and second orders (Fig. 4, Table 3).

Table 3. Morphological characteristics of the oneyear seedlings of Schisandra chinensis 'Sadovyi-1'.

\begin{tabular}{lllll}
\hline Indexes & $\mathrm{M} \pm \mathrm{m}$ & $\mathrm{Max}$ & $\mathrm{Min}$ & $\mathrm{CV}, \%$ \\
\hline Height, cm & $11.6 \pm 1.7$ & 14.7 & 9.5 & 14.9 \\
Main root length, $\mathrm{cm}$ & $9.2 \pm 2.8$ & 14.5 & 6.5 & 30.9 \\
$\begin{array}{l}\text { Number of lateral } \\
\text { roots }\end{array}$ & $4.0 \pm 1.3$ & 25.0 & 2.0 & 32.3 \\
$\begin{array}{l}\text { Number of leaves } \\
\text { Number of buds }\end{array}$ & $10.0 \pm 2.8$ & 14.0 & 5.0 & 29.1 \\
\hline
\end{tabular}

Note. $\mathrm{M} \pm \mathrm{m}$ - mean value and standard deviation; Max - maximal value; Min - minimal value; CV - coefficient of variation. 

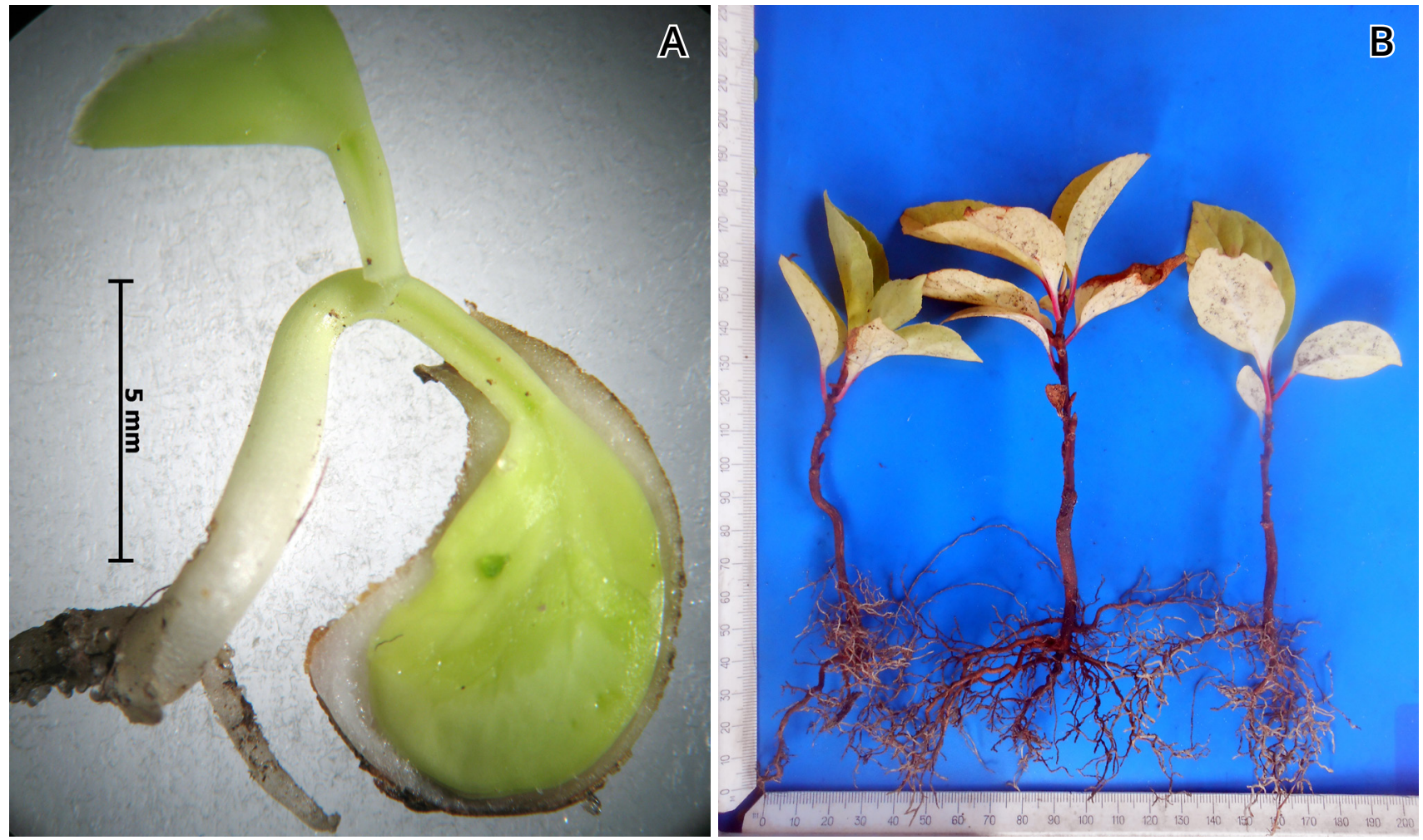

Figure 4. Sprouts with seed coat (A) and one-year seedlings (B) of Schisandra chinensis 'Sadovyi-1'.

\section{Conclusions}

The seeds of S. chinensis 'Sadovyi-1' of the local reproduction have a high content of the fatty oils (37.5\%) that mostly contains such unsaturated fatty acids as oleic (80.0-81.1\%) and linoleic (14.6-15.7\%). Therefore they are very unstable in storage and quickly become oxidized. The storage of seeds increases the acidity of fatty oils, decreases their content, and changes individual fatty acids' content.

The optimal storage conditions for S. chinensis 'Sadovyi-1' seeds were without light access and with decreased temperature $\left(+4^{\circ} \mathrm{C}\right)$, which inhibited oxidative and other biochemical processes.

The optimal is a spring sowing of stratified seeds and an autumn sowing of freshly reaped seeds, followed by its natural stratification. Under such conditions, the ground germination of S. chinensis seeds is the highest and reaches up to $65 \%$ and $63 \%$, respectively.

\section{References}

Alekseichuk, G. N., \& Laman, N. A. (2005). Physiological quality of agricultural plants seeds and methods for its assessment. Minsk: Law \& Economics. (In Russian)
Footitt, S., Huang, Z., Clay, H., Mead, A., \& FinchSavage, W. E. (2013). Temperature, light and nitrate sensing coordinate Arabidopsis seed dormancy cycling resulting in winter and summer annual phenotypes. Plant Journal, 74, 1003-1115. https://doi.org/10.1111/tpj.12186

Gonchar, O. M. (Ed.). (2000). Methods for determining the quality of crop products. Kyiv: Alefa. (In Ukrainian)

Gurevich, A. S. (2012). Pre-adaptation and morphophysiological processes of plants. Saarbrücken: Lap Lambert Academic Publishing.

Inyushin, V. M. (1981). Laser beam and the harvest. Alma-Ata: Kainar. (In Russian)

Kharkevich, S. S., \& Kachura, N. N. (1981). Rare plant species of the Soviet Far East and their protection. Moscow: Nauka. (In Russian)

Kolbasina, E. I. (2000). Actinidia and magnolia-vine in Russia (biology, introduction, selection). Moscow: Rosselhozakademia. (In Russian)

Kolbasina, E. I., Kozak, N. V., Moroz, P. A., Skrypchenko, N. V., Solovyova, L. V., \& Tulnova, N. N. (2008). Cultural flora of Russia: Acktinidia. Magnolia-vine. Moscow: Rosselhozakademia. (In Russian)

Kolotova, G. K., \& Nikolaeva, M. G. (1981). Influence of stratification conditions and phytohormones on the germination of Chinese magnolia-vine seeds and Actinidia kolomikta. Plant Resources, 17(4), 544-550. 
Lebeda, A. F., Jurenko, N. I., Isajkina A. P., \& Sobko, V. G. (2006). Medicinal plants: The most complete encyclopedia. Moscow: AST-Press. (In Russian)

Malov, A. I., \& Vigorskiy, U. N. (2002). Physics of laser biostimulation. Moscow: MILTA-PKP GIT. (In Russian)

McDonald, M. (1999). Seed deterioration: Physiology, repair and evaluation. Seed Science and Technology, 27(1), 177-237.

Nikolaeva, M. G., Razumova, M. V., \& Gladkova, V. N. (1985). Germination guide for dormant seeds. Leningrad: Nauka. (In Russian)

Nowak, A., Zakłos-Szyda, M., Błasiak, J., Nowak, A., Zhang, Z., \& Zhang, B. (2019). Potential of Schisandra chinensis (Turcz.) Baill. in human health and nutrition: A review of current knowledge and therapeutic perspectives. Nutrients, 11(2), 333. https://doi.org/10.3390/nu11020333

Osadchyi, V. I., Kosovets, O. O., \& Babichenko, V. M. (Eds.). (2010). Climate of Kyiv. Kyiv: Nika-Centr.

Plekhanova, M. N. (1990). Actinidia, magnolia-vine, honeysuckle. Leningrad: Agropromizdat. (In Russian)

Rivis, J. F., \& Fedoruk, P. S. (2010). Quantitative chromatographic methods for the determination of particular lipids and fatty acids in biological material: a manual. Lviv: Spolom. (In Ukrainian)

Roberts, E.H.(Ed.).(1972).Viabilityofseeds. Dordrecht: Springer. https://doi.org/10.1007/978-94-0095685-8
Saunders, R. M. K. (1997). A taxonomic revision of Schisandra section Sphaerostema (Schisandraceae). Edinburgh Journal of Botany, 54(3), 265-287. https://doi.org/10.1017/ S0960428600004133

Skrypchenko, N. V., Kushnir, N. V., \& Sljusar, G. V. (2017). Schizandra chinensis in the collection of the M. M. Grishko National Botanical Garden of the Ukrainian NAS in Kyiv. Annals of Warsaw University of Life Sciences - SGGW Horticulture and Landscape Architecture, 38, 43-50. https://doi.org/10.22630/ AHLA.2017.38.5

Soppe, W. J. J., \& Bentsink, L. (2016). Dormancy in plants. https://doi.org/10.1002/9780470015902. a0002045.pub2

Szopa, A., Ekiert R., \& Ekiert, H. (2016). Current knowledge of Schisandra chinensis (Turcz.) Baill. (Chinese magnolia vine) as a medicinal plant species: A review on the bioactive components, pharmacological properties, analytical and biotechnological studies. Phytochemistry Reviews, 16(2), 195-218. https://doi.org/10.1007/s11101016-9470-4

Tytlianov, A. A. (1959). Actinidia and magnolia-vine. Vladivostok: Seaside. (In Russian)

Willis, C. G., Baskin, C. C., Baskin, J. M., Auld, J. R., Venable, D. L., Cavender, B. J., Donohue, K., \& Rubio de Casas, R. (2014). The evolution of seed dormancy: Environmental cues, evolutionary hubs, and diversification of the seed plants. New Phytologist, 203, 300-309. https://doi. org/10.1111/nph.12782

\section{Насіннєва продуктивність та особливості розмноження Schisandra chinensis в умовах Національного ботанічного саду імені М.М. Гришка НАН України}

Надія Скрипченко *, галина Слюсар

Національний ботанічний сад імені М.М. Гришка НАН України, вул. Тимірязєвська, 1, Київ, 01014, Україна; * actinadiia@gmail.com

Викладено відомості про особливості насіннєвої продуктивності та розмноження Schisandra chinensis за умов інтродукції у Національному ботанічному саду імені М.М. Гришка Національної академії наук України (НБС). Дослідження виконано у 2016-2018 роках на експериментальних ділянках і в лабораторії НБС з застосуванням рослин та насіння S. chinensis сорту 'Садовий-1' селекції НБС. Вивчення зрізів здійснено за допомогою мікроскопа Carl Zeiss STEMI 2000-S. Якісний і кількісний склад вищих жирних кислот визначено за допомогою хроматографа НР-6890. Встановлено, що насіння лимонника місцевої репродукції вирізняється значно нижчим відсотком невиповненого насіння (10\%) порівняно з насінням з природного ареалу (30-90\%). Під час тривалого зберігання в насінні лимонника спостерігалися біохімічні перетворення. Зокрема, після зберігання насіння протягом десяти місяців вміст жирів та білків зменшився з 37,5 до 28,0 \% та з 19,7 до 11,2% відповідно, 
кислотність олії зросла з 2,42 до 5,7 мг КОН/г, а їі̆ йодне значення знизилося з 32,5 до 30,3 г 2 / 100 г. У жирній олії насіння лимонника виявлено високий вміст лінолевої кислоти, що становить 80$81,1 \%$ від загального вмісту жирних кислот. Визначено якісний і кількісний склад жирних кислот насіння S. chinensis у разі зберігання за різних умов освітлення та температури, який свідчить про їх несуттєвий вплив на кислотне число олії та кількісний вміст жирних кислот. Визначено оптимальні умови зберігання насіння (без доступу світла та за температури $+4{ }^{\circ} \mathrm{C}$ ), що сприяє зниженню інтенсивності окислювальних процесів у насінні та забезпечує найвищий показник його проростання. Оптимальними способами розмноження насіння лимонника $є$ весняний посів стратифікованого насіння та осінній посів свіжозібраного насіння, що проходить стратифікацію в природних умовах, які забезпечують схожість насіння 65 та 63 \% відповідно.

Ключові слова: Schisandra chinensis, насіння, термін зберігання, особливості розмноження, біохімічний склад 